\title{
CRANIOMETRIC FEATURES OF THE POPULATION OF EUROPEAN BEAVER (Castor fiber L.,1758)
}

\author{
Włodzimierz Nowicki, Witold Brudnicki, Krzysztof Kirkiłło-Stacewicz*, Benedykt Skoczylas, Jan Wach \\ UTP University of Science and Technology, Faculty of Animal Breeding and Biology, Department of Physiology, Zoophysiotherapy and \\ Animal Feeding, Bernardyńska 6, 85-029 Bydgoszcz, Poland
}

*Corresponding author, E-mail:krzysztof.stacewicz@o2.pl

\begin{abstract}
The studies of the craniometric features in European beaver (CastorfiberL.,1758) were performed using the material of 25 skulls, including 12 females and 13 males from the Pomorze and Kujawy region. For each skull 30 measurements were taken to provide the grounds for the variation in craniometric features and the significance of differences between sexes. In two cases there were observed significant and in three - highly significant differences between males and females of that species. Interestingly, in the shaft of the occipital bone there was found a profound and vast fossa of the skull base.
\end{abstract}

Key words: craniometry; skull; mandible; beaver

\section{Introduction}

Both in terms of functionality and due to the anatomy, the skull is one of the most complicated osseous structures. The sizes of single bones differ for each animal species. The differences result from the order, species and breed the animal represents, which is reflected in the animal classification.

The values of the measurements taken reflect specific features of the skull as well as the effect of the brain size on its shape. In general, the craniometric

Received:5December 2017

Accepted for publication: 16 April 2019 studies also consider odontometric elements due to their morphological interdependence, despite the fact that tooth must be considered as a part of the digestive system and thus it should not be treated as a component of skeleton. However, upon the teeth development, staring an independent food uptake makes it possible to observe the consequences of the operation of the masticatory apparatus in the skull (1).

The applicable literature offers mostly reports on the skull description; publications on a direct craniometric analysis are much less frequent. Some authors present skull transformations during skull growth. 
The most common material for the study of metrical features involved mostly the skulls of rodents. The pioneer of such studies in Poland was Dehnel $(2,3)$ who, monitoring the development cycle of skulls Mikromammalia observed a phenomenon of a periodical reduction in the cranial capacity in genus Neomyx and Sorex. Wasilewski (4) formulated similar conclusions in bank vole (Clethrionomysglareolus). Ruprecht (5), on the other hand, performed studies on the effect of the place of origin and gender dimorphism on the skull sizes in muskrat.

The reports by Empel (6) on the skull in wild rabbit demonstrated the effect of the age on some parameters of the cerebral and facial part.

The literature seems to offer some reports on the craniometric measurements of beaver skull. Comparisons of the beaver skulls from the Neolithic times with the contemporary skulls from the Wielkopolska region in Poland were made by Komosa et al. (7). The studies show that the animal age affects respective skull measurements. With age, usually the external sagittal crest and the palate length usually get larger. Rybczyński (8) showed differences in the anatomy of contemporary Canadian beavers and fossil skulls of that species.

The aim of this paper is to provide morphometric characteristics of the European beaver skull in the area of kujawsko-pomorskie province and determining the proportions in its anatomy.

\section{Materials and methods}

The observations of the craniometric features in European beaver were performed on 25 skulls, including 12 females and 13 males.

The material was received as a result of reduction cull in the area of the kujawskopomorskie province. The animal-use studies were prospectively approved by an animal care and use committee at the UTP - University of Science and Technology. The animals varied in age. Adult individuals were investigated.

The heads were separated from the carcass and exposed to thermal treatment. Having removed soft tissues, the skulls were bleached in $10 \%$ perhydrol solution.

On each skull there were marked craniometric points and 30 measurements were taken according to the method proposed by Driesch (9). A detailed description of the methods and how the measurements were taken are given below. For each skull the following measurements were taken: $(A-P)$ - total length, $(C b-P)$ - condylobazal length, $(B-P)$ - basal length, (Ect- $A)$ - the upper neurocranium length, (A-N)- cranial length, (Zl$P)$ - viscerocranium length; (Zy-Zy)- zygomatic breadth, (St-P)- viscerocranial base length, (Rhi-N)- the greatest length of nasal bones, (Po$S t)$ - the palatine horizontal lamina length, (ab)the greatest diameter of auditory bulla, (ec)breadth dorsal to the external auditory meatus, (Pml) -premolar tooth length, (M1-M3) - molar teeth row length, (Ect-Ect) - frontal breadth, (Eu$E u)$ - the greatest neurocranium breadth, $(N-B)$ angular neurocranium length, $(A-B)$ - skull height, (FMH) -foramen magnum height, (FMW)- foramen magnum width, $(O C W)$ - the greatest occipital condyles breadth, $(J P W)$ - the greatest jugular processes base breadth, $(P 1 \mathrm{~m})$ the mandible height before P1, (Id-goc)- the mandible length, (M1m)- height of mandible before M1, (GovCr)- the mandible ramus height, (M1-M1)- the intermandibular width for the first molars, $(M W)$ the intermandibular width, $(E t-B)$ - cranial cavity depth.

Measurement of cranial capacity was made using a shot no. 6 with a diameter of $2.5 \mathrm{~mm}$. The Duerst method was applied to weigh the amount of shot in the cranial cavity and compare that with the weight of $100 \mathrm{~cm}^{3}$ of the same type of shot.

The measurement-taking methods are presented in Figs 1-6. The results have been presented in Tables 1 and 2. The following were calculated: the arithmetic mean, standard deviation, coefficient of variation. With the method of the analysis of variance with T-test, there were identified the differences in the values of respective measurements between females and males.

Statistica PL program was used for statistical analysis.

\section{Results}

The beaver skull demonstrates a low, elongated, flattened-from-the-top profile. At the same time it represents the type of sciuromorphic skull in rodents. Characteristic features are wide zygomatic bones with large arcs and very massive mandible bones. The orbit is always open. The back-of-neck wall is formed by the occipital bone, ensuring the communication between the skull 
and the spinal column. In the centre one will find a vast foramen magnum connecting the cranial cavity with the vertebral canal.

Above the foramen magnum you will find the squamous part of the occipital bone the upper border of which creates a clear crest. The lateral parts in a form of jugular processes go down askew and neighbour with mastoid processes of the temporal bone. At the place where the jugular processes communicate with the squamous part of the occipital bone there occur two endosteal foramens. On the basilar part of the occipital bone there is a quite deep and vast fossa (Fig. $1-\mathrm{F})$. The fornix of the fossa is made by a very narrow osseous plate. The sphenoid bone together with basioccipital part form the skull base. The sphenoid bone in beaver has been formed from a few osseous units which maintain some independence. The axial part of the sphenoid bone is formed by the shaft built from the rostral part from the presphenoid bone and basisphenoid bones. On both sides of the presphenoid bones there occur two bones in a form of vertical laminas, forming orbital wings. Caudally to them, on the sides of the basisphenoid bone there occur small temporal wings. Between the pterygoid bone and the vertical lamina of the palatine bone there is a vast opening. Internally to the temporal wings there are found uncinate pterygoid bones limiting the vast opening.

The skull fornix in European beaver is made up by vast parietal bones, and clearly visible, and quite a large interparietal bone. On the skull fornix there is clearly visible sagittal crest which splits rostrally running symmetrically to zygomatic processes of the frontal bones. Symmetrical temporal bones make lateral surfaces of neurocranium; what is characteristic is a small squamous part which in its initial fragment gives off the zygomatic process running lateral. Around the acoustic opening, there occurs a surrounded prominent skeleton of auditory canals. From the lower part of auditory canals there run osseous crests towards the lower surface of tympanic bulla. The mastoid part laterally creates a narrow osseous surface and from the side of the backof-neck surface it supplements the osseous space between the squamous part and jugular processes of the occipital bone.

The frontal bones in beaver supplement the fornix of the skull and their surface is relatively inconsiderable. The frontal lamina neighbours with the nasal, incisive and zygomatic bones. The orbital plate fills the upper part of the orbit. On the frontal bone there occur poorly marked zygomatic processes. The ethmoid bone separates the cranial cavity from the nasal cavity. It is built from small cribriform plates separated with a relatively wide crista galli. Ethmoturbinates fill the caudal part of the nasal cavity and form the ethmoid labyrinth there.

The fornix of the nasal cavity is made up by nasal bones, in the rostral part - quite wide, they get narrowed caudally and, wedge-like, get squeezed between frontal bones. Caudal borders of the nasal bones reach towards the back, far beyond the caudal end of the incisive bones. The incisive bones in beaver are relatively large, their dorsal parts gets squeezed between the nasal bones and frontal bones. The lateral surfaces are vast, with a clearly visible, running across, swelling. In those bones there are imbedded extremely large and well-developed incisor teeth. The maxillae are a continuation of the lateral surface of viscerocranium; there in deep alveoli, there are imbedded premolar tooth and molar teeth. The deep and vast infraorbital fossa of jawbones makes up the attachment for a part of the rumen. The lower part of fossa which is defined by the osseous crest makes the infraorbital foramen visible. The zygomatic bone makes up the main component of the zygomatic arch, communicating with the maxilla which, in a form of a think osseous lamella makes the anterior border of the zygomatic arch. The upper fragment of the zygomatic bone forms the anterioventral border of the orbit. A small frontal process does not limit the orbit clearly. In its lower part the zygomatic bone gives off temporal process, which anastomoses with the zygomatic process of temporal process. The lacrimal bone, small in size on the skull fornix, in a form of a small osseous lamella goes then onto the anterior surface of the orbit. The bone includes a vast lacrimal foramen. The palatine bones form together with palatine lamina of the maxilla of hard palate. On the border of the connection of those bones, visible double palatine foramens which are usually located asymmetrical. At the bottom of the nasal cavity there runs the nasal vomer which ends up at the $2 / 3^{\text {rd }}$ of the length of the nasal cavity.

Mandible in beaver relatively large, supplementing the ventral part of the skull makes it assume the shape of a very heavily obtuse wedge. 

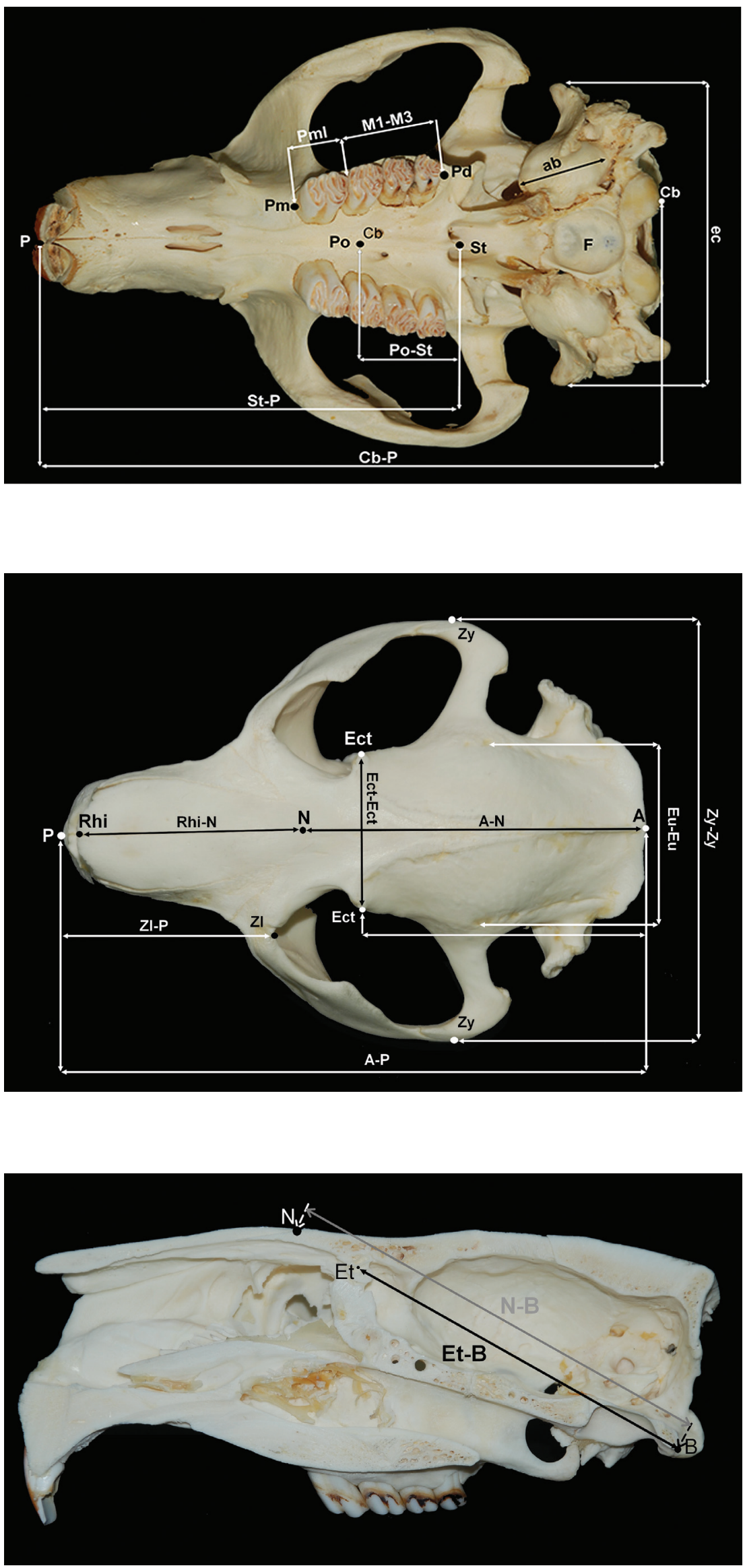

Figure 1: The beaver skull - ventral view

(Cb-P)- condylobazal length, (St-P)- viscerocranial base length, (Po-St)- palate length, (ab)-the greatest diameter of auditory bulla, (ec)- breadth dorsal to the external auditory meatus, (M1-M3) - molar teeth row length, (Pml) -premolar tooth length, F - shaft of the occipital bone

Figure 2: The beaver skull - dorsal view

(A-P)- total length, (A-N) - cranial length, (Zy-Zy)- zygomatic breadth, (Rhi-N)- the greatest length of nasal bones, (Ect-Ect) frontal breadth, (eu-eu) - the greatest neurocranium breadth, (Z1-P) - viscerocranium length

Figure 3: Cranial cross-section in beaver

(N-B)- angular neurocranium length, (Et-B) - cranial cavity depth 
Figure 4: The beaver skull - planum nuchale view

(A-B)- skull height, (FMH) -foramen magnum height, (FMW)- foramen magnum width, (OCW)- the greatest occipital condyles breadth, (JPW)- the greatest jugular processes base breadth

Figure 5: The mandible of beaver - side view

(P1m) - the mandible height before P1, (Idgoc)- the mandible length, (M1m)- height of mandible before M1, (Gov-Cr)- the mandible ramus height

Figure 6: The mandible of beaver - dorsal view

(M1-M1) - the intermandibular width for the first molars, (MW)- the intermandibular width
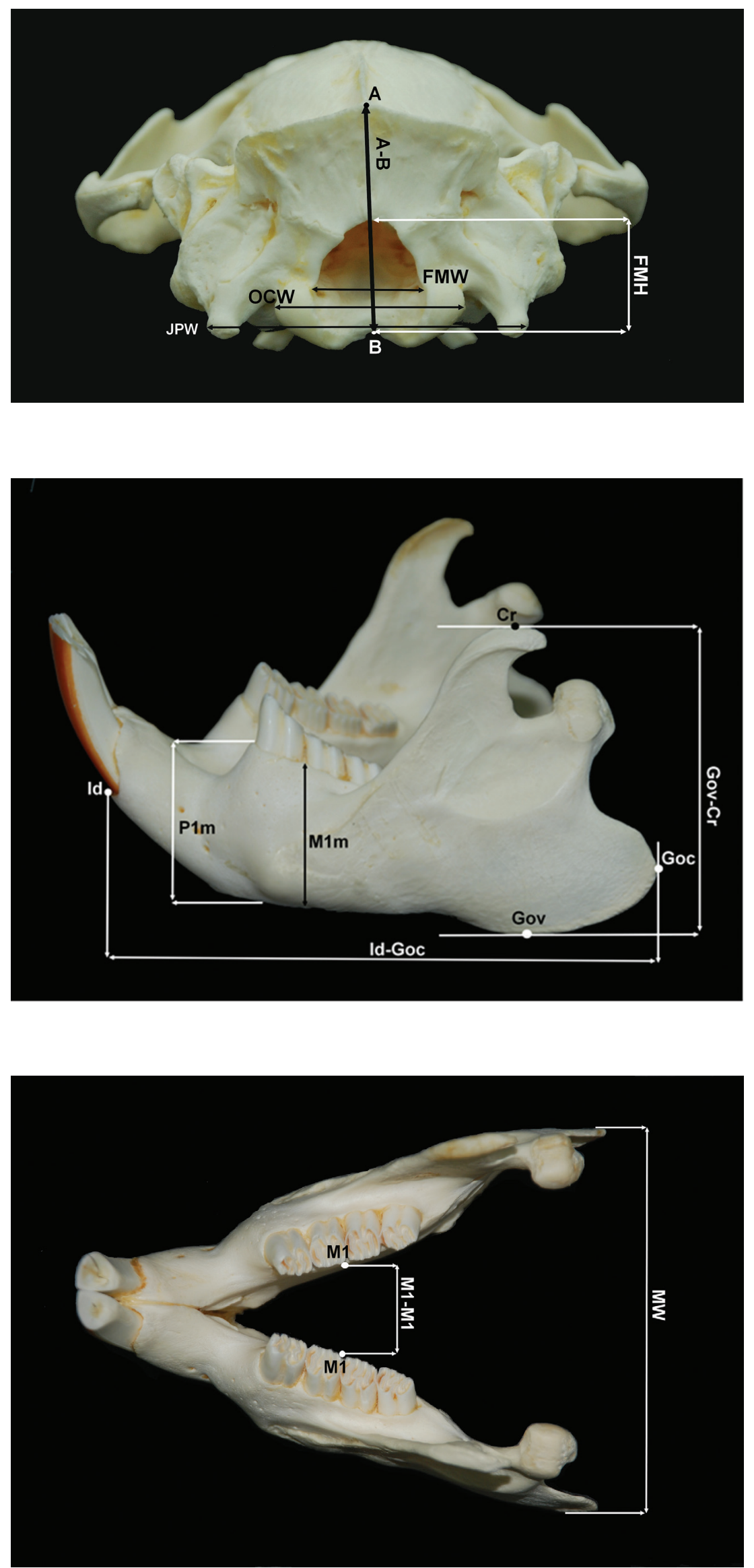
The inferior part of the border of the mandible together with the border of the fornix determine the angle of $30^{\circ}$. The mandible is a double bone; both mandibles, the right one and the left one, communicate with each other in intermandible synchondrosis. The connection in beaver is quite permanent. The mandible body relatively high in the anterior part includes a vast dental alveolus for lower incisors. In the caudal part it ends up with a vast angular process. The branch of the mandible includes two processes: the coronoid process and condyloid process. Between the condyloid process and the angular process there occurs quite a deep cut.

In the maxilla and mandible there occur a total of 20 teeth: 2 incisors each, 2 premolar teeth each, and 6 molar teeth each. Between the incisors and premolar teeth there is a vast free space - diastema. Incisors are strongly arc-bent, from the front covered with brown-orange enamel, chisel-like-finished. The premolar teeth and molar teeth are similar to each other, their masticatory surface forms transverse enamel folds, it allows for crushing even the finest food. All the teeth are rootless, continuously attrited with wear and tear they stick out throughout their life from alveoli. According to the craniometric examinations, the largest total length $(A-P)$ was $14.77 \mathrm{~cm}$ in males. This parameter in the female group was characterized by a higher coefficient of variation of $4.21 \%$, the difference between the two groups was $0.95 \mathrm{~cm}$ and was not statistically significant.

The highest condylobazal length $(C b-P)$ in males was $14.04 \mathrm{~cm}$, while in females it was $13.67 \mathrm{~cm}$. The coefficient of variation was $2.53 \%$ and $7.53 \%$, respectively. The difference between these groups was statistically insignificant.

The upper neurocranium length (Ect-A) was $8.42 \mathrm{~cm}$ in males and $7.13 \mathrm{~cm}$ in females. The difference between the groups was statistically significant. We also observe a fairly high coefficient of variation in females, which is $7.99 \%$ compared to males, where it was only $1.49 \%$.

In the case of cranial length $(A-N)$ the measurement was $8.92 \mathrm{~cm}$ in males and $9.12 \mathrm{~cm}$ in females. Coefficient of variation was $12.22 \%$ in females and only $3.08 \%$ in males.

Very high statistically significant differences between males and females were recorded for the angular neurocranium length $(N-B)$ and the difference was $0.3 \mathrm{~cm}$.

Yet another parameter measured which dem- onstrates a high significance of the difference between the groups was the length of the viscerocranium $(Z l-P)$. In females one can see a high value of the coefficient of variation $(10.06 \%)$ which in the male group accounts for $2.89 \%$ only. This measurement is also characterized by the high significance of the difference between the studied groups.

The greatest length of nasal bones $(R h i-M)$ as one of the few parameters was characterized by the high significance of the differences, while the minimum and maximum values were at a similar level.

The length of the palate $(\mathrm{PO}-\mathrm{St}$ ) was characterized by a high coefficient of variation of $10.49 \%$ in the female group, which was significantly lower in comparison with males.

In the case of the greatest diameter of auditory bulla $(a b)$, also in females the coefficient of variation was twice as high, but the difference between means was not statistically significant.

One of the measured parameters is the breadth dorsal to the external auditory meatus (ec), which is distinguished only by a very high coefficient of variation in females $-9.77 \%$.

One shall consider the length of the row of molar teeth noteworthy; with its outstanding high coefficient of variation accounting for $11.60 \%$ in the male group. In females, on the other hand, it was $5.15 \%$. The measurement showed significant differences across the means. The frontal width of the skull is the parameter that is the only one characterized by a similar and high coefficient of variation in both the group of females and males. Accordingly, it is $10.52 \%$ and $11.38 \%$.

The frontal breadth (Ect-Ect) is the only parameter that has similar and a high coefficient of variation in both males and females, $10.52 \%$ and $11.38 \%$ respectively.

The largest internal eye height reached the highest variability coefficient among all tested males and was $12.10 \%$.

The next measured parameters were: skull height, cranial length and occipital cap height, values not statistically different between groups.

The measurement of the height of the foramen magnum showed the highest value of the coefficient of variation in females and it accounted for $19.54 \%$. It was the highest value of all the 74 measurements in total. Besides, the difference between the sexes was highly significant. The other measurements of the occipital bone (foramen 
Table 1: Statistical characteristics of the caniometric measurements in European beaver

\begin{tabular}{|c|c|c|c|c|c|c|c|c|}
\hline No & Measurement & Sex & $\mathrm{n}$ & $\mathrm{x}$ & RANGE & $\mathrm{S}_{\mathrm{x}}$ & $\mathrm{V}_{\mathrm{x}}$ & Difference \\
\hline \multirow{2}{*}{1} & \multirow{2}{*}{ A-P } & 0 & 21 & 14,00 & $11,58-14,77$ & 0,40 & 2,86 & \multirow{2}{*}{0,95} \\
\hline & & 우 & 19 & 13,05 & $12,50-14,70$ & 0,55 & 4,21 & \\
\hline \multirow{2}{*}{2} & \multirow{2}{*}{$\mathrm{Cb}-\mathrm{P}$} & o & 21 & 13,46 & $9,99-14,04$ & 0,39 & 2,13 & \multirow{2}{*}{0,96} \\
\hline & & q & 19 & 12,49 & $11,59-13,67$ & 0,94 & 7,53 & \\
\hline \multirow{2}{*}{3} & \multirow{2}{*}{ B-P } & o & 21 & 13,98 & $13,84-14,14$ & 0,91 & 0,65 & \multirow{2}{*}{$0,87^{* *}$} \\
\hline & & q & 19 & 13,11 & $12,82-13,39$ & 1,98 & 1,51 & \\
\hline \multirow{2}{*}{4} & \multirow{2}{*}{ Ect-A } & o & 21 & 6,85 & $6,37-8,40$ & 0,10 & 1,46 & \multirow{2}{*}{$0,05^{*}$} \\
\hline & & 우 & 19 & 6,80 & $5,99-7,29$ & 0,54 & 7,94 & \\
\hline \multirow{2}{*}{5} & \multirow{2}{*}{ A-N } & 0 & 21 & 8,69 & $5,19-8,89$ & 0,27 & 3,10 & \multirow{2}{*}{0,83} \\
\hline & & q & 19 & 7,85 & $7,09-9,16$ & 0,96 & 12,20 & \\
\hline \multirow{2}{*}{6} & \multirow{2}{*}{$\mathrm{Zl}-\mathrm{P}$} & 0 & 21 & 6,04 & $5,36-7,90$ & 0,17 & 2,81 & \multirow{2}{*}{$-0,10^{* *}$} \\
\hline & & q & 19 & 6,15 & $5,72-6,52$ & 0,62 & 10,08 & \\
\hline \multirow{2}{*}{7} & \multirow{2}{*}{$Z y-Z y$} & $\hat{0}$ & 21 & 10,39 & $8,06-11,91$ & 0,54 & 5,20 & 077 \\
\hline & & 우 & 19 & 9,62 & $8,79-11,98$ & 0,53 & 5,51 & 0,17 \\
\hline 8 & St_P & 0 & 21 & 9,06 & $7,96-9,21$ & 0,24 & 2,65 & 57 \\
\hline 8 & St-P & q & 19 & 8,49 & $7,73-9,67$ & 0,54 & 6,36 & 0,51 \\
\hline & & 3 & 21 & 2,95 & $2,59-3,49$ & 0,25 & 8,47 & \\
\hline 9 & Rh1-N & q & 19 & 3,02 & $2,21-3,21$ & 0,22 & 7,28 & $-0,07 \times x$ \\
\hline & & o & 21 & 1,23 & $0,99-1,42$ & 0,05 & 4,06 & \\
\hline 10 & Po-St & 우 & 19 & 1,17 & $1,10-1,31$ & 0,12 & 10,26 & 0,06 \\
\hline & & 0 & 21 & 1,73 & $1,38-1,90$ & 0,06 & 3,47 & \\
\hline 11 & $a b$ & 운 & 19 & 1,59 & $1,25-1,91$ & 0,11 & 6,92 & 0,13 \\
\hline & & $\hat{0}$ & 21 & 1,75 & $1,32-1,91$ & 0,09 & 5,14 & \\
\hline 12 & ec & 운 & 19 & 1,63 & $1,54-2,01$ & 0,16 & 9,81 & 0,11 \\
\hline 13 & Pm1 & $\widehat{0}$ & 21 & 1,03 & $0,92-1,07$ & 0,12 & 11,65 & $003 *$ \\
\hline 13 & $\mathrm{Pml}$ & 웅 & 19 & 1,00 & $0,77-1,19$ & 0,05 & 5,00 & $0,03^{n}$ \\
\hline 14 & M1 M2 & $0^{3}$ & 21 & 2,21 & $1,79-2,34$ & 0,09 & 4,07 & 013 \\
\hline 14 & $1011-\ln 13$ & 우 & 19 & 2,08 & $2,02-2,48$ & 0,13 & 6,25 & 0,10 \\
\hline 15 & Fet_Fet & $\hat{0}$ & 21 & 3,20 & $2,31-3,41$ & 0,36 & 11,25 & 030 \\
\hline 15 & Ect-Ect & 우 & 19 & 2,89 & $2,69-3,79$ & 0,30 & 10,38 & 0,30 \\
\hline & & o & 21 & 3,71 & $3,02-3,94$ & 0,11 & 2,96 & \\
\hline 16 & Eu-Eu & q & 19 & 3,54 & $2,99-3,97$ & 0,20 & 5,65 & 0,16 \\
\hline & & $\hat{0}$ & 21 & 8,99 & $8,91-9,13$ & 0,59 & 6,56 & \\
\hline 17 & N-B & 우 & 19 & 8,69 & $8,60-8,78$ & 0,72 & 8,28 & $3,02^{* *}$ \\
\hline & $A$ & o & 21 & 3,89 & $2,99-3,98$ & 0,05 & 1,28 & \\
\hline 18 & A-B & q & 19 & 3,68 & $2,91-4,02$ & 0,26 & 7,06 & 0,22 \\
\hline & & 3 & 21 & 1,49 & $1,17-2,31$ & 0,15 & 10,07 & \\
\hline 19 & FMH & q & 19 & 1,57 & $1,25-1,77$ & 0,31 & 19,74 & $-0,08^{* *}$ \\
\hline 20 & FMW & $\hat{0}$ & 21 & 1,73 & $1,36-1,94$ & 0,04 & 2,31 & 011 \\
\hline 20 & FIVIW & q & 19 & 1,62 & $1,57-1,82$ & 0,07 & 4,32 & 0,11 \\
\hline 21 & OCW & o & 21 & 3,13 & $2,79-3,32$ & 0,05 & 1,60 & 014 \\
\hline 21 & ucw & 우 & 19 & 2,99 & $2,89-3,19$ & 0,08 & 2,67 & 0,14 \\
\hline 20 & IPW & 0 & 21 & 5,53 & $4,69-5,89$ & 0,17 & 3,07 & O 30 \\
\hline 22 & JPW & 우 & 19 & 5,24 & $5,18-5,63$ & 0,22 & 4,20 & 0,30 \\
\hline & & $\hat{0}$ & 21 & 7,77 & $73,39-79,96$ & 1,63 & 2,90 & \\
\hline 23 & Et-B & q & 19 & 7,67 & $75,47-73,39$ & 0,84 & 1,09 & $0,98^{*}$ \\
\hline 04 & & o & 21 & 41,54 & $39-43$ & 1,39 & 3,35 & $0,04^{*}$ \\
\hline 24 & Capacity [ml] & 우 & 19 & 41,50 & $40-43$ & 1,00 & 2,41 & 0,45 \\
\hline
\end{tabular}


Table 2: Statistical characteristics of craniometric measurements of mandible in European beaver

\begin{tabular}{|c|c|c|c|c|c|c|c|c|}
\hline No & Measurement & Sex & $\mathrm{n}$ & $\mathrm{x}$ & RANGE & $\mathrm{S}_{\mathrm{x}}$ & $\mathrm{V}_{\mathrm{x}}$ & Difference \\
\hline \multirow{2}{*}{25} & \multirow{2}{*}{$\mathrm{P} 1 \mathrm{~m}$} & $\hat{0}$ & 21 & 3,41 & $3,01-3,49$ & 0,16 & 4,69 & \multirow{2}{*}{0,17} \\
\hline & & 우 & 19 & 3,24 & $3,19-3,75$ & 0,16 & 4,94 & \\
\hline \multirow{2}{*}{26} & \multirow{2}{*}{ Id-goc } & $\hat{0}$ & 21 & 10,76 & $8,88-10,81$ & 0,18 & 1,67 & \multirow{2}{*}{0,59} \\
\hline & & 우 & 19 & 10,17 & $10,49-11,19$ & 0,47 & 4,62 & \\
\hline \multirow{2}{*}{27} & \multirow{2}{*}{$\mathrm{M} 1 \mathrm{~m}$} & $\widehat{0}$ & 21 & 3,02 & $2,19-3,12$ & 0,08 & 2,65 & \multirow{2}{*}{0,23} \\
\hline & & 운 & 19 & 2,79 & $2,88-3,14$ & 0,26 & 9,32 & \\
\hline \multirow{2}{*}{28} & \multirow{2}{*}{ Gov-Cr } & $\hat{0}$ & 21 & 6,18 & $5,65-6,29$ & 0,09 & 1,46 & \multirow{2}{*}{0,15} \\
\hline & & 우 & 19 & 6,03 & $5,89-6,32$ & 0,16 & 2,65 & \\
\hline \multirow{2}{*}{29} & \multirow{2}{*}{ M1-M1 } & $\widehat{0}$ & 21 & 1,64 & $1,33-1,99$ & 0,07 & 4,27 & \multirow{2}{*}{$0,02 *$} \\
\hline & & q & 19 & 1,62 & $1,51-1,77$ & 0,18 & 11,11 & \\
\hline \multirow{2}{*}{30} & \multirow{2}{*}{ MW } & $\hat{0}$ & 21 & 7,86 & $6,62-8,30$ & 0,28 & 3,56 & \multirow{2}{*}{0,45} \\
\hline & & 우 & 19 & 7,41 & $6,44-8,26$ & 0,64 & 8,64 & \\
\hline
\end{tabular}

magnum width and occipital condyles as well as the greatest width of base of jugular processes) were non-significant.

Interestingly, the highest width of jugular processes demonstrated the lowest value of the coefficient of variation among the two groups and it accounted for $2.21 \%$ in females and $0.92 \%$ in males.

The largest mandibular width (M1-M1) reached a high value of variation coefficient in females $(11.39 \%)$ and the difference was statistically significant.

For other mandibular measurements, i.e. (P1m) the mandible height before P1, (M1m)- height of mandible before M1, $(M W)$ - the intermandibular width, (Gov-Cr)- the mandible ramus height, (Id-goc)- the mandible length no statistically significant differences between the sexes were noticed.

The study of cranial cavity capacity and its length $(E t-B)$ showed statistically significant differences between sexes.

In conclusion, among the 30 measurements received, only in five cases differences were statistically highly significant and in five cases it was statistically significant.

\section{Discussion}

The studies of the metric variation in the European beaver skull have facilitated determining characteristic features of the species. The skull of the beaver, the biggest rodents living in Poland, is an extremely massive structure, slightly flattened from the top. Among the mammal order it represents the type of sciuromorphic structure. The characteristic feature of the beaver skull, both extinct and contemporary forms, are wide zygomatic bones with large arches and very massive mandible bones with wide shafts (8).

A specific feature if the beaver skull is, unusual in other mammal species, a vast and deep fossa of the skull base covered with mucous membrane. In literature, you cannot find any information about the role of this structure in the life of beavers. The applicable literature seems not to offer information on the role it plays in the life of that species.

The beaver skull shows a slight effect of sexual dimorphism on the variation in the craniometric features. Of all the parameters analysed only 3 measurements differed highly significantly and they concerned the following parameters: the length of the viscerocranium, the greatest length of nasal bones, cranial base length, the height of foramen magnum and angular height of the neurocranium. A similarly inconsiderable variation resulting from sexual dimorphism was noted in muskrat by Ruprecht (5). Assuming the standard deviation as the measure of population variations, one can assume that the Kujawy-Pomorze beaver population shows a slight variation in craniometric features and the only exception is the total length of the skull and the condylobazal length where the standard deviation reached higher values. 
The studies of the craniometric features facilitated providing characteristics of the Kujawy -Pomorze European beaver population. The measurements show that the average total length of the beaver skull in females was $13.05 \mathrm{~cm}$ and in males $-14.00 \mathrm{~cm}$. Yet another parameter usually described when providing skull characteristics is the maximum skull width, measured in zygomatic arches the mean of which was also higher in the male group and it accounted for $10.39 \mathrm{~cm}$, while in females - for $9.62 \mathrm{~cm}$. Considering at least one parameter connected with the mandible, it is noteworthy mentioning the maximum width of diaphyseal processes since the difference across the means in both groups was one of the few significant ones.

Considering the coefficient of variation, it assumed the highest value among the females and it accounted for $19.74 \%$ for (FMH) -foramen magnum height. The lowest value of the parameter was $0.65 \%$, for the basal length (B-P) which refers to males. Both values are a threshold at the same time for the group of females and males studied.

\section{References}

1. Brudnicki W. Comparison of craniometric features and cranial cavity volume in domestic pig (Sus scrofa forma domestica) and wild boar (Sus scrofa) in view of development. Folia Biol Kraków 2005; 53(Suppl.): 25-30.
2. Dehnel A. Research on genus Sorex L. Ann. UMCS 1949: sect. c IV:2.

3. Dehnel A. Research on genus Neomys. Ann. UMCS 1950: sect. c IV:1.

4. Wasilewski W. Un ersuchunger über die morphologische Veränderlichkeit der Erdmans (Microtusagrestis L.). Ann Univ Mariae Curie-Sklodowska C 1956; 9: 6.

5. Ruprecht AL. Craniometric variation in central European population of Ondatra Zibethica (Linneus 1766). Acta Theriol 1974; 19(31): 463507.

6. Empel W. Observations on cranial capacity concerning postnatal development in wild rabbit (Oryctolagus cuniculus). Folia Morphol 1958: 3(9): 225-30.

7. Komosa M., Frackowiak H., Godynicki S. Skulls of neolithic Eurasian beavers (Castor fiber L.) in comparison with skulls of contemporary beavers from natural biotopes of Wielkopolska Region (Polska). Pol J Environ Stud 2007; 16(5): 697-705.

8. Rybczyński N, Ross EM, Samuels JX, Korth WW. Re-evaluation of sinocastor (Rodentia: Castoridae) with implications on the origin of modern beavers, PLoS One. 2010; 5(11): e13990, 1-15. https://www.ncbi.nlm.nih.gov/pmc/articles / PMC2981558/

9. Driesh A. A guide to the measurement of animal bones from archeological sites. Cambridge: Peabody Museum of Archeology and Ethnology Harvard University, 1976. 


\section{KRANIOMETRIČNE ZNAČILNOSTI V POPULACIJI EVROPSKEGA BOBRA (Castor fiber L., 1758)}

W. Nowicki, W. Brudnicki, K. Kirkiłło-Stacewicz, B. Skoczylas, J. Wach

Povzetek: Študija kraniometričnih značilnosti evropskega bobra (Castor fiberL., 1758) je bila izvedena na 25 lobanjah 12 samic in 13 samcev evropskega bobra s področij Pomorze in Kujawy na Poljskem. Navsaki lobanji je bilo opravljenih 30 meritev, ki so bile podlaga za ugotavljanje raznolikosti v kraniometričnih značilnostih in njihovem pomenu pri razlikah med spoloma. V dveh primerih so opaziliznačilne in v treh primerihzelo značilne razlike med samci in samicami. Zanimivo je, dajevzatilnicinajdena globoka in obsežna jama na bazi lobanje.

Ključne besede: kraniometrija; lobanja; mandibula; bober 